\title{
Standar Fasilitas Pelayanan Forensik dan Kamar Jenazah di Era Pandemi COVID-19
}

\author{
Erwin G. Kristanto, ${ }^{1}$ Ade Firmansyah ${ }^{2}$
}

\author{
${ }^{1}$ Bagian Kedokteran Forensik dan Medikolegal Fakultas Kedokteran Universitas Sam \\ Ratulangi, Manado, Indonesia \\ ${ }^{2}$ Departemen Kedokteran Forensik dan Medikolegal Fakultas Kedokteran Universitas \\ Indonesia, Jakarta, Indonesia \\ Email: kristantogidion@gmail.com
}

\begin{abstract}
Mortuary is one of the mandatory parts of a hospital. During the COVID-19 pandemic, the standard of morgue facilities must be a concern to prevent transmission from the corpse. The morgue needs to be designed so that it has the right placement, room design as well as equipment, so as to create a service flow that protects hospital staff and families/communities who come to mourn the corpse. Hospital management must prepare an appropriate standard of facilities, therefore, the funeral services can be carried out properly. This article aims to discuss good standards for forensic and mortuary services, and explores important options to provide mortuaries of type $\mathrm{C}$ and $\mathrm{D}$ hospitals or mobile hospitals.
\end{abstract}

Keywords: mortuary, forensic service, facility standard

\begin{abstract}
Abstrak: Kamar jenazah merupakan salah satu bagian wajib ada di sebuah rumah sakit. Pada masa pandemi COVID-19, standar fasilitas kamar jenazah harus menjadi perhatian agar tidak terjadi penularan dari jenazah. Kamar jenazah perlu didesain agar memiliki penempatan, serta desain ruangan dan alat yang tepat, agar dapat tercipta alur layanan yang melindungi staf rumah sakit dan keluarga/masyarakat yang datang untuk melayat jenazah. Standar fasilitas yang tepat harus disiapkan oleh manajemen rumah sakit agar pelayanan jenazah dapat terlaksana dengan baik. Artikel ini bertujuan untuk membahas tentang standar pelayanan forensik dan kamar jenazah yang baik, dan mengeksplorasi pilihan penyediaan kamar jenazah bagi rumah sakit tipe $\mathrm{C}$ dan $\mathrm{D}$ ataupun rumah sakit bergerak.
\end{abstract}

Kata kunci: kamar jenazah, pelayanan forensik, standar fasilitas

\section{Pendahuluan}

Kamar jenazah dijadikan syarat bagi semua rumah sakit pada saat evaluasi kelayakan rumah sakit dalam memperoleh ijin operasional. Kamar jenazah dan ruang pelayanan forensik merupakan fasilitas kesehatan yang membutuhkan perhatian khusus dalam perencanaan, pembangunan, pengoperasian, dan pemeliharaannya, terutama pada masa pandemi COVID-19 atau dalam penanganan penyakit menular lainnya di rumah sakit (RS). Pengelolaan layanan forensik dan kamar jenazah yang baik diharapkan dapat melengkapi tata laksana untuk pencegahan penularan COVID-19 bagi keluarga pasien maupun masyarakat. ${ }^{1}$

Kamar jenazah dan layanan patologi forensik perlu dicermati sejak awal proses perencanaan rumah sakit sehingga dapat tercipta alur layanan yang aman dan nyaman bagi keluarga pasien maupun staf rumah sakit. Tata letak kamar jenazah dalam perencanaan rumah sakit atau dalam pengembangan rumah sakit, harus memenuhi kriteria sebagai berikut: 1) Letak kamar jenazah memiliki akses langsung dengan ruang gawat darurat, ruang kebidanan, 
ruang rawat inap, ruang operasi, dan ruang perawatan intensif; 2) Akses menuju kamar jenazah bukan merupakan akses umum dan diproteksi terhadap pandangan pasien dan pengunjung untuk alasan psikologis; 3) Memiliki akses dan lahan parkir khusus untuk kereta jenazah; dan 4) Lahan parkir khusus untuk kereta jenazah harus berdekatan dengan kamar jenazah. ${ }^{1,2}$

Letak kamar jenazah sebaiknya dekat atau tidak terlampau jauh dari tempat pengolahan limbah rumah sakit, sehingga pembuangan limbah dari kamar jenazah, terutama limbah infeksius dapat dilakukan dengan baik. ${ }^{3}$ Selain itu, kamar jenazah harus disiapkan agar memiliki akses langsung melalui pintu masuk rumah sakit dan didesain letaknya untuk menghindari staf rumah sakit harus mentranspor jenazah melewati area publik lain di rumah sakit. Daya tampung kamar jenazah sebaiknya mencapai perbandingan 1:25 dari jumlah tempat tidur di rumah sakit, sebagai contoh bila rumah sakit memiliki 100 tempat tidur rawat inap, maka daya tampung kamar jenazah disiapkan untuk 4 jenazah. ${ }^{4}$

Berdasarkan latar belakang yang telah dipaparkan dan pentingnya kamar jenazah dalam mencegah penularan COVID-19, maka penulis terdorong untuk membahas standar bagi sebuah kamar jenazah, baik di rumah sakit yang melaksanakan pelayanan forensik maupun yang hanya melaksanakan pelayanan pemulasaraan jenazah. Standar kamar jenazah yang diulas pada tulisan ini merupakan penyatuan standar yang ditetapkan Kementerian Kesehatan RI, Komisi Akreditasi Rumah Sakit, dan Pedoman dari Perhimpunan Dokter Forensik Indonesia.

\section{Bangunan Kamar Jenzah}

Kamar jenazah dan ruang pelayanan forensik harus didesain untuk memberi ruang yang cukup bagi staf teknis dan dokter untuk bekerja dan mampu menampung peralatan yang digunakan untuk pelayanan forensik dan pelayanan kamar jenazah. Fasilitas untuk pelayanan forensik khususnya patologi forensik dan kamar jenazah idealnya memiliki ruangan sebagai berikut: 1) Ruang dekontaminasi jenazah; 2) Ruang pemulasaraan/pelayanan jenazah; 3) Ruang administrasi; 4) Ruang tunggu keluarga; 5) Ruang staf dan dokter; 6) Kamar mandi dan ruang ganti; 7) Ruang autopsi; 8) Ruang pendingin mayat; 9) Ruang laboratorium forensik; 10) Ruang upacara/ruang duka; dan 11) Gudang perlengkapan termasuk gudang bahan berbahaya (B3). ${ }^{1,2}$

Kamar jenazah setidaknya harus memiliki satu akses masuk dan satu akses keluar yang terpisah serta 1 pintu keluar darurat. Pada rumah sakit yang lebih kecil, kamar jenazah didesain terdiri dari beberapa ruang terpisah, yang setidaknya terdiri atas: ruang pelayanan jenazah, ruang administrasi, ruang staf dan dokter, dan ruang untuk mandi, menggunakan alat pelindung diri (APD), dan melepas APD. ${ }^{3,4}$

Luas ruangan pemulasaraan jenazah minimal $12 \mathrm{~m}^{2}$ dengan meja tindakan atau meja autopsi. Penempatan alat harus memperhatikan ketersediaan ruang gerak dari tenaga pelaksana. Luas ruang pemulasaraan jenazah harus didesain untuk mampu memfasilitasi pergereakan troli jenazah dari dan ke meja tindakan. Pada ruang pelayanan jenazah harus disediakan tempat mencuci tangan. Pada setiap ruangan harus tersedia minimal 2 (dua) kotak sumber listrik. Pada rumah sakit yang hanya memiliki satu kamar jenazah, maka ruang pelayanan untuk kasus COVID-19 dan yang bukan kasus COVID-19 perlu dipisahkan. Pada rumah sakit yang melaksanakan pelayanan patologi forensik, maka ruang pelayanan jenazah perlu dilengkapi dengan peralatan yang menunjang pelayanan pemeriksaan patologi forensik. Ruang autopsi bagi jenazah COVID-19 ini berada di tekanan negatif terhadap daerah sekitarnya, memiliki minimal enam perubahan udara per jam (air changes per hour/ACH) untuk struktur yang ada dan $12 \mathrm{ACH}$ untuk struktur yang direnovasi atau baru, dan udara dibuang langsung di luar gedung atau disaring melalui filter high-efficiency particulate air (HEPA). Kamar autopsi juga dapat juga didesain menggunakan ventilasi alam dengan kecepatan minimal 160L/detik/orang. Pintu ke kamar autopsi harus tetap tertutup kecuali selama masuk dan keluar., 3 
Kamar jenazah perlu memiliki ruang ganti untuk mengenakan APD yang terpisah dengan ruang ganti untuk melepaskan APD, terutama pada kamar jenazah yang melayani pasien dengan COVID-19. Kamar mandi juga perlu disediakan untuk membasuh diri setelah melakukan tindakan. Alur masuk dan keluar staf dan dokter di kamar mandi dan ruang ganti perlu diatur sehingga tidak menimbulkan kontaminasi pada saat menggunakan atau melepas APD. ${ }^{5,6}$

Ruangan pemulasaraan jenazah dan ruang dekontaminasi jenazah perlu didesain dengan konstruksi dinding tahan air sampai ketinggian $120 \mathrm{~cm}$ dari permukaan lantai. Pada ruang dekontaminasi jenazah ruangan harus dilengkapi dengan sink dan pancuran air (shower). Lantai ruangan dekontaminasi dan pemulasaraan didesain agar tidak licin saat terkena air. Pintu masuk ruang pemulasaraan jenazah dibuat membuka ke arah dalam dan dilengkapi dengan alat penutup pintu otomatis. Ruang pemulasaraan jenazah dan autopsi harus dilengkapi dengan pencuci mata (eye washer) untuk kepentingan keselamatan staf, saat terjadi cipratan pada mata oleh cairan tubuh mayat atau zat berbahaya lain seperti formaldehid. Ruang autopsi dan ruang pemulasaraan sebaiknya memiliki bagian dengan pembatas kaca transparan (viewing window) agar orang yang berada di luar ruang autopsi dapat melihat ke dalam. ${ }^{1,7}$

Ruang dekontaminasi, ruang pemulasaraan dan ruang autopsi harus memiliki sistem saluran pembuangan limbah cair yang terhubung alat pengolah limbah cair dilengkapi dengan alat ukur swapantau kualitas air limbah. ${ }^{6}$ Pengolah limbah ini dikelola oleh Instalasi Pengolahan Air Limbah (IPAL) RS. Ruang dekontaminasi dan ruang pemulasaraan jenazah juga harus dilengkapi peralatan dengan permukaan stainless steel, termasuk tempat sampah dan lemari penyimpan yang ada di dalam ruang tersebut. ${ }^{1,8}$

Pada rumah sakit yang menyediakan ruangan pendinginan jenazah, luasnya disesuaikan dengan kapasitas pelayanan. Ruang pendinginan jenazah secara standar harus dibagi dua; yang pertama untuk menampung jenazah yang belum membusuk dan yang kedua digunakan untuk menampung jenazah yang sudah membusuk. Masing-masing ruang ini setidaknya berukuran 3,5 x 6 meter $\left(21 \mathrm{~m}^{2}\right)$ sehingga total ruang pendingin jenazah setidaknya berukuran $42 \mathrm{~m}^{2}$. Ruangan setidaknya memiliki ventilasi mekanik atau ventilasi alami dan terhubung dengan ruang tindakan di kamar jenazah. Mesin pendingin jenazah harus dapat mencapai suhu rerata maksimal $4^{0} \mathrm{C}$ untuk pendinginan mayat jangka pendek (tidak lebih dari 2 hari) dan suhu rerata maksimal $-10^{\circ} \mathrm{C}$ untuk pendinginan mayat jangka panjang. Pencatatan suhu lemari pendingin harus dilakukan setiap hari dan bila terjadi variasi suhu di atas ambang batas, maka petugas kamar jenazah harus segera menghubungi teknisi rumah sakit. ${ }^{1,5}$

Laboratorium forensik idealnya didesain dengan luas minimal $12 \mathrm{~m}^{2}$ per meja autopsi dengan memperhatikan ruang gerak petugas, pasien dan peralatan. Laboratorium didesain agar terhubung dengan kamar autopsi tanpa harus keluar dari pintu keluar staf. Di dalam laboratorium harus tersedia fasilitas desinfeksi tangan, penerangan cukup, akses air untuk penggunaan laboratorium, akses listrik dan eye washer. ${ }^{5,9}$

Gudang perlengkapan dan gudang bahan berbahaya dan beracun (B3) dibangun dengan ukuran sesuai kebutuhan, diberi penerangan yang baik, dan dilengkapi penerangan yang cukup dan lemari B3 yang tahan api. Lemari penyimpanan harus diberi label yang mencantumkan isi dalam lemari dan tanda bahan berbahaya yang ada di dalamnya. Gudang perlengkapan dan B3 ini harus dilengkapi dengan pengukur suhu dan kelembaban. Gudang perlengkapan dan gudang bahan berbahaya harus memiliki ruang yang cukup untuk menyimpan bahan habis pakai, seperti kantung jenazah dan bahan habis pakai lain, termasuk perlengkapan upacara jenazah; lemari dengan kunci untuk menyimpan barang milik jenazah sebelum diserahkan pada keluarga; tempat penyimpanan linen bersih yang terpisah dengan penyimpanan linen kotor; dan bahan berbahaya dan beracun (B3). ${ }^{6}$

Kamar jenazah selain dilengkapi 
dengan pintu darurat, setidaknya harus memiliki tiga pintu yaitu satu pintu untuk staf, satu pintu untuk jenazah dari rumah sakit atau dari luar rumah sakit, dan satu pintu untuk pengunjung/pelayat jenazah. Ruang upacara atau ruang yang digunakan untuk menunjukkan jenazah pada keluarga harus didesain memiliki akses langsung ke jalan. Gambar 1 memperlihatkan alur pasien/ jenazah di kamar jenazah, sedapat mungkin alur didesain dengan baik agar keluarga/ pelayat yang datang untuk melihat atau mengupacarakan jenazah, tidak berkontak dengan bagian yang membawa risiko infeksi di kamar jenazah.,

\section{Ventilasi Udara}

Pengkondisian udara di ruang pelayanan patologi forensik dan kamar jenazah rumah sakit mempunyai peran yang lebih penting dari sekedar faktor kenyamanan staf dan keluarga pasien. Pada ruang pelayanan patologi forensik dan kamar jenazah RS, pengkondisian udara yang tepat merupakan faktor utama dalam menghindari kontaminasi hasil pemeriksaan dan pencegahan terjadinya infeksi nosokomial. ${ }^{4}$

Pada penanganan pasien atau jenazah berpenyakit menular terutama COVID-19, upaya untuk menonaktifkan virus dengan sinar ultra violet dan semprotan kimia belum terbukti dapat diandalkan atau cukup efektif untuk direkomendasikan sebagai tindakan pengendalian infeksi primer. Oleh karena itu isolasi ruang dan isolasi ruang antara (ante room) dengan perbedaan tekanan dan ventilasi yang tepat merupakan sarana utama yang digunakan untuk mencegah penyebaran virus di lingkungan rumah sakit. ${ }^{2,4}$

Intake udara ruang pelayanan patologi forensik atau kamar jenazah harus ditempatkan sejauh mungkin dari outlet pembuangan dengan paparan yang berbeda secara terarah dari outlet pembuangan udara, atau memiliki jarak tetapi tidak kurang dari 9 $\mathrm{m}$ dari cerobong outlet buangan. Letak intake udara luar untuk kamar jenazah harus ditempatkan tidak kurang dari 1,8 $\mathrm{m}$ di atas permukaan lantai, atau bila intake dibuat di atas atap, letak intake dibuat pada $0,9 \mathrm{~m}$ di atas permukaan atap. ${ }^{2,8}$

Outlet pembuangan udara ruang pelayanan patologi forensik dan kamar jenazah harus ditempatkan minimal $3 \mathrm{~m}$ di atas permukaan lantai dan jauh dari pintu, area tempat berkumpukl atau lewat orang, dan jendela ruangan. Outlet pembuangan sebaiknya didesain berdiri tegak atau bila dibuat horizontal, maka harus dipastikan ditempatkan jauh dari intake udara luar., ${ }^{2,10,11}$

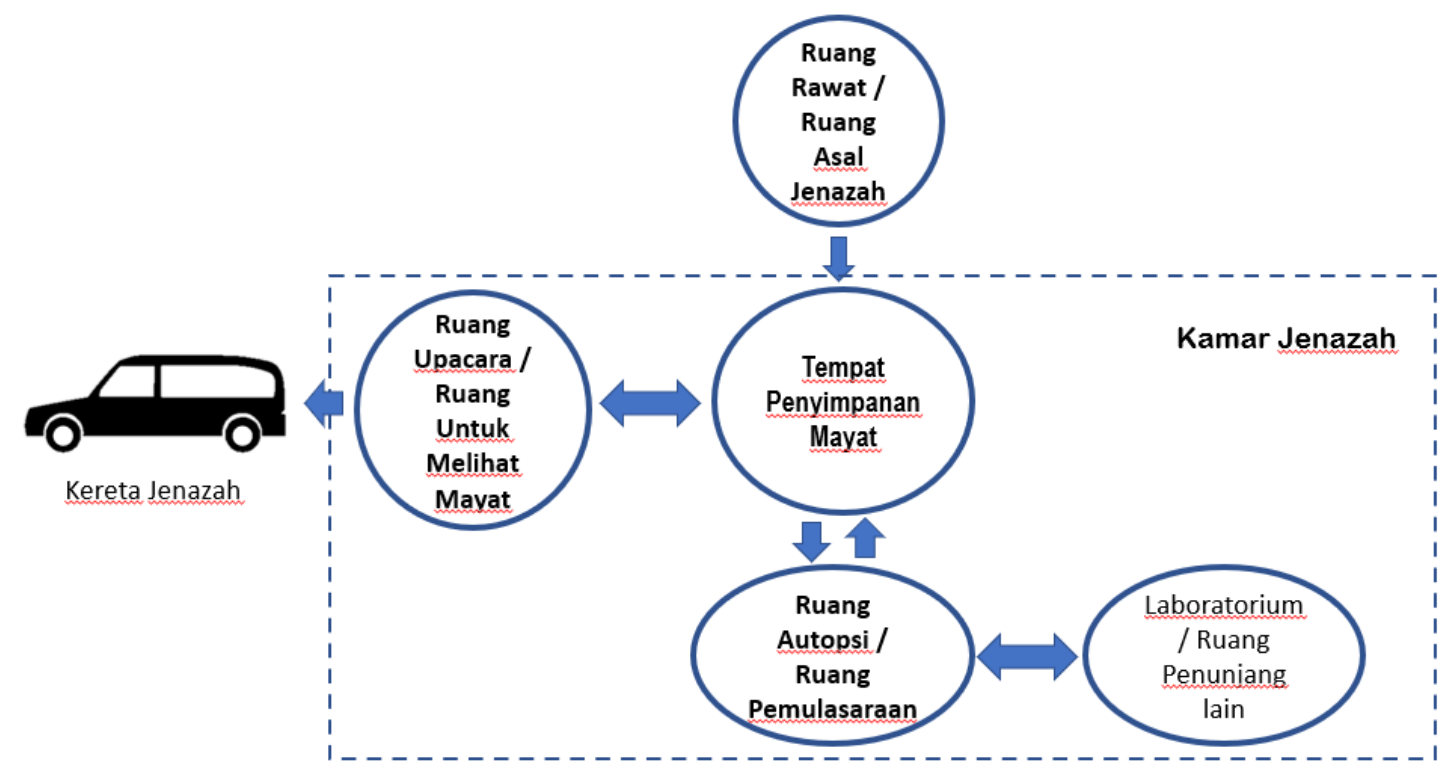

Gambar 1. Alur pelayanan jenazah ${ }^{3,6}$ 
Partikulat yang masuk dari aliran udara, perlu disaring dengan filter, dan semua ventilasi atau sistem pengkondisian udara di rumah sakit harus dilengkapi dengan filter. Untuk penggunaan di kamar jenazah sebaiknya digunakan dua dudukan filter, dudukan filter pertama diletakan di hulu dari peralatan pengkondisian udara dan dudukan filter kedua ditempatkan di hilir kipas pasok udara. Filter harus dipasang dengan tepat untuk mencegah kebocoran antar segmen filter atau antar dudukan filter serta rangka penopang. Kebocoran kecil pada pemasangan filter akan memungkinkan udara yang terkontaminasi berjalan tanpa tersaring; hal ini dapat menghilangkan kegunaan filter sebagai pembersih udara. Pada sistem filter perlu didesain untuk dipasang sebuah manometer untuk mengukur penurunan tekanan. $^{2,12}$

Pada ruang tindakan di kamar jenazah atau rumah sakit yang memiliki ruang autopsi, maka perhatian terhadap ruang ini terutama pada kontaminasi bakteri dan bau. Intake buangan harus ditempatkan baik di langit-langit atau di sisi rendah dinding. Sistem buangan harus mengalirkan udara di atas atap rumah sakit. Suatu tekanan negatif relatif terhadap sekitarnya harus disediakan di ruang autopsi untuk mencegah penyebaran kontaminasi. Apabila sejumlah besar formalin digunakan, tudung pembuangan khusus mungkin diperlukan untuk menjaga konsentrasi sampai tingkat di bawah ketentuan yang berlaku. ${ }^{2,8}$

Pada ruang tindakan kamar jenazah atau pada ruang autopsi kasus COVID-19 di rumah sakit yang tidak memungkinkan penggunaan unit airborne infection isolation room (AIIR) atau HEPA, prosedur harus dilakukan di lingkungan yang paling protektif. Udara tidak boleh dikembalikan ke interior bangunan, tetapi harus digunakan di luar ruangan, jauh dari area lalu lintas manusia atau ruang berkumpul dan jauh dari sistem asupan udara lainnya. ${ }^{10,12}$

Pada rumah sakit yang lebih kecil dan tidak memiliki ruang autopsi, kontrol lokal dari sistem ventilasi dan sistem kontrol bau bisa menggunakan karbon aktif atau potasium permanganat dipenuhi alumina aktif, dengan tetap memperhatikan aliran udara agar tidak dikembalikan ke interior bangunan atau area yang menjadi tempat lalu lalang atau berkumpul orang. ${ }^{10,11}$

\section{Peralatan}

Pelayanan forensik dan kamar jenazah selain harus didukung oleh unit lain seperti instalasi sterilisasi sentral, sistem informasi terpadu RS, dan penunjang lain, pelayanan ini secara khusus memerlukan peralatan: meja autopsi/meja pemulasaraan mayat, set autopsi, alat pencahayaan untuk kepentingan forensik, peralatan radiologi portable, brankar jenazah, peralatan antropometri, kantung mayat, plastik pembungkus mayat, apron plastik, tutup kepala, label jenazah, perlengkapan laboratorium forensik, alat pengumpul sampel, dan formulir terkait layanan forensik dan kamar jenazah. ${ }^{12}$

Alat pelindung diri yang digunakan dokter dan staf kamar jenazah untuk melakukan autopsi atau tata laksana jenazah yang terinfeksi atau diduga terinfeksi COVID-19 harus sesuai dengan prosedur autopsi atau tata laksana jenazah yang meninggal akibat penyakit pernafasan akut atau penyakit air-borne lain. Seseorang yang meninggal akibat COVID-19 pada tubuhnya atau cairan tubuhnya masih terdapat virus yang hidup. Sebuah laporan kasus di Italia menunjukkan ditemukannya post mortem swab yang positif bahkan setelah 35 hari pasca kematian. ${ }^{13}$ Alat pelindung diri yang sesuai harus tersedia di kamar jenazah termasuk baju scrub, jubah berlengan panjang yang kedap air, sarung tangan (dua pasang sarung tangan atau satu pasang sarung tangan autopsi), masker medis, pelindung mata (pelindung wajah atau kacamata gogel), dan sepatu bot/ pelindung kaki. ${ }^{6,7}$

Jenazah terinfeksi atau diduga terinfeksi COVID-19 setelah tata laksana yang lain selesai dilakukan, maka jenazah kembali dimandikan dan semua lubang pada tubuh jenazah ditutup dengan kapas yang dibaluri klorin. Jenazah kemudian dibungkus dengan plastik yang tidak mudah koyak, kemudian diletakkan pakaian atau dikafankan. Jenazah yang telah dikafan atau diletak- 
kan pakaian di atasnya, dibungkus kembali dengan kantung jenazah atau plastik yang tidak mudah bocor kemudian dimasukkan ke dalam peti yang kedap air. Setelah peti ditutup, peti dibungkus dengan plastik tebal. Pada setiap pembungkusan dengan plastik, pada permukaan plastik disemprot dengan larutan antiseptik. Setelah semua prosedur ini dilakukan, jenazah baru dapat dibawa keluar kamar jenazah untuk diangkut dengan kereta jenazah ke pekuburan. ${ }^{3,7}$

\section{Pembersihan Fasilitas dan Lingkungan}

Perencanaan dalam pemilihan alat di kamar jenazah harus memperhatikan agar permukaan dan instrumen yang digunakan untuk merawat/melakukan tata laksana jenazah harus terbuat dari bahan yang mudah dibersihkan, didesinfeksi, dan dipelihara di antara tindakan pada jenazah. Virus korona (COVID-19) dapat bertahan hingga 9 hari pada permukaan fasilitas/alat di kamar jenazah, terutama benda seperti logam, kaca, atau plastik. Virus ini telah terdeteksi hingga 72 jam pada kondisi eksperimental di permukaan alat atau bahan yang terbuat dari plastik dan stainless steel. Fakta ini menunjukkan bawah pembersihan permukaan fasilitas dan lingkungan sangatlah penting. ${ }^{11}$

Semua instrumen yang digunakan selama pelaksanaan tata laksana jenazah di kamar jenazah, di rumah duka, atau selama autopsi harus dibersihkan dan didesinfeksi segera setelah digunakan, sebagai bagian dari standar prosedur operasi di kamar jenazah. Permukaan lingkungan, meja tindakan, dan instrumen pertama-tama dibersihkan dengan sabun dan air, atau larutan disinfektan yang dibuat secara komersial. Setelah permukaan dibersihkan, dilakukan disinfeksi menggunakan natrium hipoklorit dengan konsentrasi minimal 0,1\% (1000 ppm), atau etanol $70 \%$ setidaknya selama satu menit. Petugas yang melakukan pembersihan harus menggunakan APD yang sesuai, termasuk pelindung mata, saat menyiapkan dan menggunakan disinfektan. Semua cairan dan bahan yang diklasifikasikan sebagai limbah klinis harus ditangani dan dibuang dengan benar sebagai limbah infeksius dan sesuai dengan persyaratan hukum. ${ }^{11,12}$

\section{Konflik Kepentingan}

Penulis menyatakan tidak terdapat konflik kepentingan dalam studi ini.

\section{DAFTAR PUSTAKA}

1. Peraturan Menteri Kesehatan Nomor 27 Tahun 2017 tentang Pedoman Pencegahan dan Pengendalian Infeksi di_Fasyankes. Available from: http://hukor.kemkes. go.id/uploads/produk_hukum/PMK No._27_ttg_Pedoman_Pencegahan_da n_Pengendalian_Infeksi_di_FASYAN KES_.pdf

2. Peraturan Menteri Kesehatan Nomor 24 tahun 2016 tentang persyaratan teknis bangunan dan prasarana rumah sakit. Available from: https://dinkes.kedirikab.go.id/ konten/uu/97467PMK_No._24_ttg_Per syaratan_Teknis_Bangunan_dan_Prasa rana_Rumah_Sakit.pdf

3. Sugiharto AF, Syukrinani YFS, Meilia PDIM, Yudy, Tanzilah S, Wiraagni IAW, et al. Pedoman interim tata laksana jenazah yang membutuhkan pelayanan forensik patologi pada masa pandemic COVID19. Jakarta: Perhimpunan Dokter Forensik Indonesia. Kolegium Kedokteran Forensik Indonesia, 2020.

4. Dubai Health Authority. Standards for Mortuary Services. Dubai: Health Policies and Standards Department Health Regulation Sector, 2020.

5. Australian Government Department of Health. National Pathology Accreditation Advisory Council. Requirements for the Facilities and Operation of Mortuaries (3rd edition). Available from: https: //www.health.gov.au/internet/main/pub lishing.nsf/Content/health-npaac-docsmortuari.htm

6. Sutoto. Instrumen Survei Standar Nasional Akreditasi Rumah Sakit (1.1st edition). Jakarta: Komisi Akreditasi Rumah Sakit, 2018.

7. Pedoman Kesiapsiagaan menghadapi infeksi novel corona virus (2019-nCOV). Jakarta: Direktorat Jenderal PPI Kementerian Kesehatan, 2020. Available from: https://infeksiemerging. kemkes.go.id/download/DOKUMEN_ RESMI_Pedoman_Kesiapsiagaan_nCo V_Indonesia_28_Jan_2020.pdf 
8. Direktorat Bina Pelayanan Penunjang Medik Dan Sarana Kesehatan. Pedoman Teknis Prasarana Sistem Tata Udara pada Bangunan Rumah Sakit. Jakarta: Kementerian Kesehatan, 2012. Available from: http://manajemenr rumahsakit.net/wp-content/uploads/ 2012/11/Pedoman-Teknis-Tata-Udaracomplete.pdf

9. Purwanto B. Engineering control: Tata udara dan tata ruang RS di Era Pandemi COVID-19. Seminar online Komisi Akreditasi Rumah Sakit: Peran stake holder dalam mendukung RS menghadapi lonjakan COVID-19. Webinar KARS: 18 Januari 2021.

10. Peraturan Menteri Kesehatan Republik Indonesia Nomor 7 Tahun 2019
Tentang Kesehatan Lingkungan Rumah Sakit. Available from: http://hukor. kemkes. go.id/uploads/produk_hukum/ PMK_No_7_Th_2019_ttg_Kesehatan _Lingkungan_Rumah_Sakit.pdf

11. Purwadianto A, Hamurwono BG, Setyowati LR, Rosita R, Suseno U, Kandouw YM, et al. Standar Kamar Jenazah. Jakarta: Departemen Kesehatan RI, 2004.

12. Clinical management of COVID-19: interim guidance. Geneva: World Health Organization; 2020.

13. Beltempo P, Curti SM, Maserati R, Gherardi M, Castelli M. Persistence of SARSCoV-2 RNA in post mortem swab 35 days after death: a case report. Forensic Sci Int. 2021;319:110653. 